\title{
Genes Underlying Reproductive Division of Labor in Termites, with Comparisons to Social Hymenoptera
}

\author{
Judith Korb * \\ Evolutionary Biology and Ecology, University of Freiburg, Freiburg, Germany
}

All social insects are characterized by a reproductive division of labor. Within a colony only a few individuals reproduce (queens and in termites, also a king) while the large majority (workers and soldiers) forgo reproduction, at least temporarily. The evolution of such reproductive altruism can ultimately be explained by inclusive fitness theory. Here, I will review the proximate genetic mechanisms underlying this altruism in termites. As social cockroaches they evolved eusociality independently from the social Hymenoptera, which makes them interesting test cases to look for common underlying mechanisms of eusociality and lineage specific idiosyncrasies. First, I will provide a summary of the genes and their function that have been identified to underlie reproductive division of labor-so called "queen genes," - in the drywood termite Cryptotermes secundus, an emerging model to study termite social evolution. Second, I outline how widespread

OPEN ACCESS

Edited by:

Graham J. Thompson, Western University, Canada

Reviewed by:

Michael Griesser,

University of Zurich, Switzerland Luke Holman,

University of Melbourne, Australia

*Correspondence:

Judith Korb

judith.korb@biologie.uni-freiburg.de

Specialty section:

This article was submitted to Social Evolution,

a section of the journal

Frontiers in Ecology and Evolution

Received: 14 December 2015 Accepted: 12 April 2016 Published: 26 April 2016

Citation:

Korb J (2016) Genes Underlying

Reproductive Division of Labor in Termites, with Comparisons to Social Hymenoptera. Front. Ecol. Evol. 4:45.

doi: 10.3389/fevo.2016.00045 these queen genes are across the termite phylogeny, using also evidence from recent genome analyses. I will provide hypotheses about the evolutionary origin of these queen genes, aiming to link proximate mechanisms with ultimate functions. Finally, I will draw comparisons to social Hymenoptera to indicate potential common underpinnings that warrant further testing.

Keywords: termite, sociogenomics, reproductive division of labor, social hymenoptera, vitellogenins, P450

\section{INTRODUCTION}

A major characteristic of social insects is their reproductive division of labor between reproducing (queens, and in termites also kings) and, at least temporally, non-reproducing individuals (workers and soldiers). How such altruistic behavior that reduces an individual's direct fitness can evolve puzzled Darwin when he formulated natural selection theory (Darwin, 1859). But since more than 50 years, altruistic behavior can be explained by inclusive fitness theory (kin selection; equivalent to multi-level selection or new group selection; Hamilton, 1963, 1964; Wenseleers et al., 2010), the idea that alleles are not only selected through their effect on own offspring (direct fitness) but also by their effect on other individuals that carry the same alleles-namely, kin (indirect fitness).

In many social insects the caste fate of individuals (i.e., whether they become reproductives or workers/soldiers) is determined early during development, sometimes probably even in the egg (Wilson, 1971; Okot-Kotber, 1985). However, in all clades species with totipotent workers occur that have the capability to develop into reproductives (e.g., stingless bees, gamergates in ants, workers in lower termites). This raises the question of how reproductive division of labor is maintained in such colonies. Ultimately, restrain by others (control or manipulation by dominants) and self-restraint due to indirect fitness effects can explain why such totipotent individuals do not 
reproduce (e.g., Queller and Strassmann, 1998; Ratnieks et al., 2006). At the mechanistic level, behavioral regulation, for instance, through dominance interactions, policing, or pheromones can prevent selfish worker reproduction (e.g., Heinze and Hölldobler, 1995; Ratnieks et al., 2006; Saha et al., 2012). Studying the molecular genetic basis of reproductive division of labor combines both, the ultimate and the proximate level, as it addresses the fundamental foundations of eusociality by helping to pinpoint the underlying genes that are selected.

\section{Maintenance of Reproductive Monopoly in Termites}

Termites evolved eusociality independently from social Hymenoptera. They are "social cockroaches," a monophyletic clade (Infraorder Isoptera) nested within the Blattodea, with Cryptocercus woodroaches as sister taxon (Inward et al., 2007; Engel et al., 2009; Figure 1). According to current phylogenies they comprise nine families, which can be grouped into two major life types. Most species belong to the "separate-pieces life type," which is characterized by workers that forage outside the nest for food ("foraging termite species" hereafter; Figure 1). These species have morphologically differentiated workers with a reduced capability to reproduce (Noirot, 1985a; Roisin, 2000; Roisin and Korb, 2011). This character is linked to early caste differentiation during development and to intensive brood care by workers (Noirot, 1985a; Korb and Hartfelder, 2008; Figure 1). The separate-pieces life type contrasts with the likely ancestral life type of termites in which species nest within their food, a single piece of wood (one-piece life type; Figure 1). In these wood-dwelling termites, like the kalotermitid Cryptotermes secundus, all workers (also called pseudergates) are totipotent immatures and being a worker is a transient stage (Noirot, 1985b; Roisin, 2000; Korb and Katrantzis, 2004; Korb, 2008). Workers finally develop into either sterile soldiers (few individuals within each colony), or two types of reproductives: winged sexuals that disperse and found new colonies as primary reproductives (hereafter, primaries), or neotenic (replacement) reproductives (hereafter, neotenics) that inherit the natal colony when the king or queen dies or becomes unhealthy (Korb and Katrantzis, 2004). In kalotermitids, the presence of a king and queen (primaries or neotenics) prevents the differentiation of neotenics (Lüscher, 1974; Lenz, 1976) thus leading to reproductive division of labor within a colony. There is no aggression and rather subtle interactions and chemical communication seems to be crucial for maintenance of reproductive division of labor (Hoffmann and Korb, 2011; Hoffmann et al., 2012), probably by volatiles as well as contact pheromones (Lüscher, 1974). Volatile queen pheromones have been identified for foraging species (Matsuura et al., 2010; Himuro et al., 2011; Matsuura, 2012). As in other social insects, cuticular hydrocarbons ( $\mathrm{CHCs}$ ) can function as contact signals. Among all social insect clades, similar $\mathrm{CHC}$ compounds seem to indicate queen fertility (Van Oystaeyen et al., 2014). Accordingly, in Hymenoptera as well as wood-dwelling termites, workers restrain from reproduction when a healthy, reproducing female is present (Liebig et al., 2009; Liebig, 2010; Van Oystaeyen et al., 2014). In C. secundus reproducing queens differ from workers by the presence of long-chained, methylated
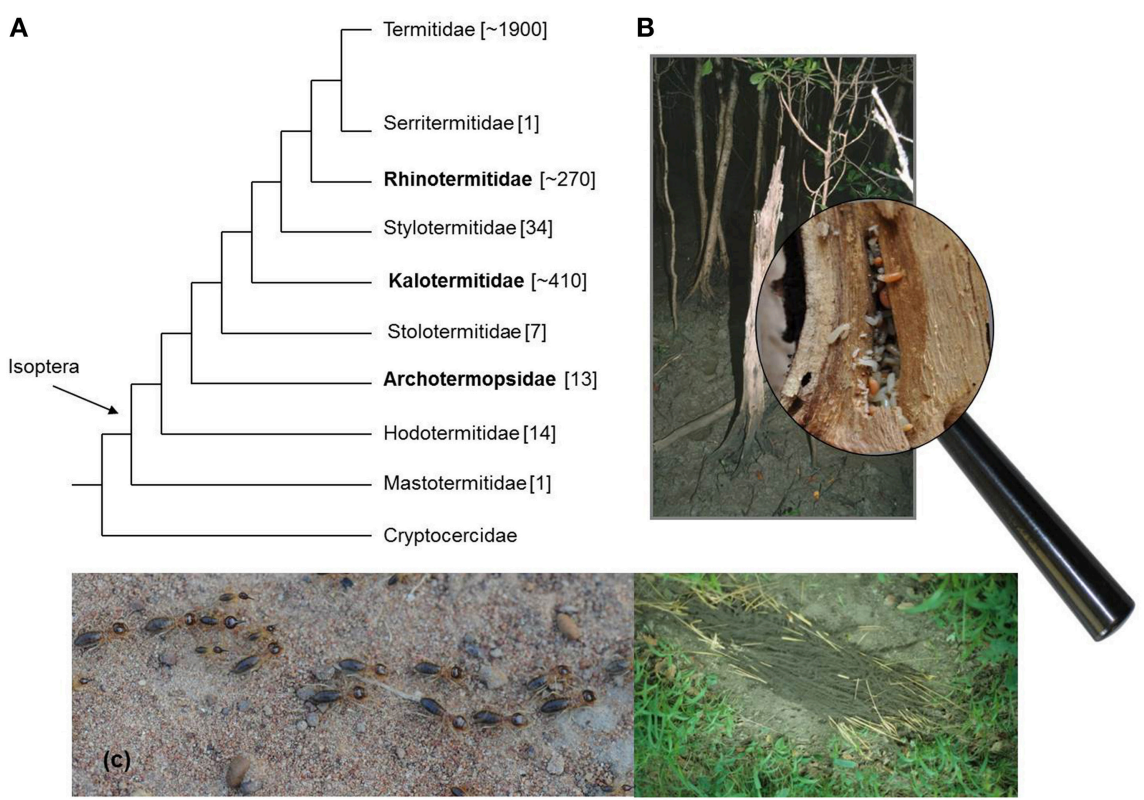

FIGURE 1 | Termite diversity. (A) Cladogram of termite families with the Cryptocercidae (woodroaches) as sister-taxon. Families with a wood-dwelling life type (one-piece nester) are in bold. Note the Rhinotermitidae have both life types. (B) Wood-dwelling termites like $C$. secundus nest in a piece of wood (often a dead tree) that serves both as food and shelter. (C) The fast majority of recent termites belong to the separate pieces life type. Here, workers and soldiers leave the nest (below or above ground) to forage outside for food outside. Shown are foraging Trinervitermes and a food source covered with soil sheeting exploited by Macrotermes bellicosus. 
and unmethylated alkanes and alkenes (Weil et al., 2009a). They are essential for maintenance of the reproductive monopoly. Experimental changes in the queen bouquet to shorter $\mathrm{CHCs}$ were associated with a breakdown of reproductive division of labor (Hoffmann et al., 2014).

\section{THE NEOFEM GENES}

In termites, primary reproductives develop gradually via several (nymphal) instars and have several conspicuous traits (e.g., wings and eyes), besides those linked to reproduction and maintenance of reproductive division of labor, that distinguish them from workers. This is different for neotenics, which in kalotermitids develop from workers via a single molt and they differ from the latter only in that they are reproducing adults that maintain reproductive monopoly (Hoffmann and Korb, 2011). Hence, to uncover genes directly underlying reproductive division of labor, neotenics are most suitable.

In the pre-genomic era, five genes have been identified that are highly over-expressed in neotenic females (called Neofem genes) by comparing neotenic queens and workers using representational difference analyses (Weil et al., 2007; Table 1). Quantitative realtime PCR (qt RT PCR) using all castes (except soldiers) confirmed that Neofem 1, 2, and Neofem 5 are specifically over-expressed in reproducing females, both neotenics and primaries. Neofem 3 seem to be over-expressed in all reproducing individuals, queens and kings, and Neofem 4 is specifically over-expressed in female neotenics (Weil et al., 2007).

\section{What Are these Genes?}

Neofem 5 is a "novel" gene for which no orthologs have yet been found. As we know too little about it, it is not further discussed. Neofem 1 encodes an esterase/lipase with some similarities to two $\mathrm{JH}$ esterases in the mosquito Aedes aegypti. But closer sequence inspection reveals that Neofem 1 is unlikely to function as a $\mathrm{JH}$ esterase (K. Hartfelder, pers. comm.).

Neofem 2 belongs to the beta-glucosidase (BG) genes affiliated with the glycosyl hydrolase family (GHF)1 (Weil et al., 2007). Their products are known as common cellulase components in bacteria, fungi, protists, plants, and animals that convert shortchained sugars in glucose (Terra et al., 1996). In termites and cockroaches, BG genes have been identified in species across all major families. They seem to be multifunctional enzymes of cellulase digestion and/or social communication (Lo et al., 2011; Shimada and Maekawa, 2014). The close match of the Neofem 2 protein to the Lma-p72 protein of the Maderian cockroach, Rhyparobia maderae, implies a pheromonal function in the termite. Lma-p72 is sex-specifically expressed in the abdominal glands of male cockroaches to attract females via release of a volatile compound (Cornette et al., 2003). This similarity makes Neofem 2 a prime candidate for further functional studies in $C$. secundus.

Neofem3 encodes a vitellogenin ( $\mathrm{Vg})$, which are large precursor proteins of vitellin, the major yolk egg protein of insects (e.g., Wheeler, 1996). They are generally synthesized in the abdominal fat body, released into the hemolymph, and sequestered by the developing oocytes. Hence, we expected a $\mathrm{Vg}$ to be over-expressed in reproducing queens. Its high expression in kings may be explained by the function of Vgs as storage proteins (Wheeler, 1996). Furthermore, Vgs apparently have been co-opted repeatedly during social evolution in social Hymenoptera, for instance, for regulation of division of labor among workers (e.g, Amdam et al., 2004, 2006; Nelson et al., 2007).

Neofem4 belongs to the cytochrome P450 genes, more specifically to family \#4, subfamily $U$ (CYP4U). CYP4 is the most highly represented insect $\mathrm{P} 450$ family. P450s are ubiquitous heme-containing oxidative enzymes found in all organisms. In insects, they can be involved in the oxidation of xenobiotic substrates that include secondary plant compounds and insecticides. In addition, a P450 gene has been found to be involved in the biosynthesis of CHCs in cockroaches (Reed et al., 1994; Howard and Blomquist, 2005) and several P450s have been linked to juvenile hormone $(\mathrm{JH})$ production or degradation (Sutherland et al., 1998; Feyereisen, 2012; Tarver et al., 2012). A CYP4C7 gene metabolizes JH in a cockroach and this is linked to ovulation (Sutherland et al., 1998, 2000). Finally, the expression of $\mathrm{P} 450$ genes can be regulated by JH (Lu et al., 1999) and JH induced expression of P450 genes has been found during soldier differentiation in termites (Cornette et al., 2006; Zhou et al., 2007; Tartar et al., 2009).

\section{Functional Characterization of Neofem2 and Neofem4}

RNA interference (RNAi) experiments of the most striking Neofem genes, Neofem 2 and Neofem4, confirmed that they are

TABLE 1 | Neofem genes and their distribution across termites.

\begin{tabular}{|c|c|c|c|c|c|c|}
\hline & \multirow[t]{2}{*}{ Protein } & \multicolumn{2}{|c|}{ C. cynocephalus } & \multicolumn{2}{|c|}{ Z. nevadensis } & \multirow[t]{2}{*}{ Supposed Function } \\
\hline & & Presence & Q-up & Presence & Q-up & \\
\hline Neofem1 & Esterase/lipase & Yes & yes & 1 & no & $?$ \\
\hline Neofem2 & Beta-glucosidase & Yes & yes & 1 & yes & Chem. comm.: volatile? \\
\hline Neofem3 & Vitellogenin & Yes & yes & $2(4)$ & yes & Fertility and others? \\
\hline Neofem4 & P450/CYP4 & Yes & No & $55(76) / 17(20)$ & yes & Chem. comm.: CHC \\
\hline Neofem5 & unknown & $?$ & $?$ & $?$ & $?$ & $?$ \\
\hline
\end{tabular}

The numbers in the column "Z. nevadensis, Presence" show the number of copies identified in the genome, numbers in brackets include genes with modified domain architecture. Q-up, overexpression in queens; chem. comm., chemical communication; ?, unknown. 
functionally involved in maintaining reproductive division of labor in C. secundus (Korb et al., 2009b; Hoffmann et al., 2014). The function of the other genes has not been tested so far. After targeted down-regulation of Neofem 2 or Neofem 4 expression in queens, workers behave as if they were in a queenless colony, implying that they do not recognize the queen any more despite her presence and a lack of changes in her queen behavior. Workers increase butting frequency, a rapid back- and forward movement of the body with or without contact to another individual. Butting is characteristic for workers that will develop into replacement neotenics after queen removal, and it is the first sign of a breakdown of the reproductive monopoly (Korb et al., 2009b; Hoffmann and Korb, 2011). Hence a high expression of Neofem 2 and Neofem4 is necessary for maintenance of reproductive division of labor in C. secundus. Unfortunately, RNAi only lasts for up to $48 \mathrm{~h}$ (Korb et al., 2009b), which is too short to observe neotenic development.

The genes' identity implied that both may function via chemical communication. Down-regulation of Neofem 2 via RNAi does not affect the $\mathrm{CHC}$ profile of queens, but for Neofem 4 it does. Silencing Neofem 4 changes the profile of queens toward a more worker-like composition of shorter-chained $\mathrm{CHC}$ (Hoffmann et al., 2014). Thus, Neofem4 is involved in the production of the royal scent. We hypothesize that its expression is simultaneously linked to the queens' fertility, probably via a $\mathrm{JH}$ mediated mechanism, so that Neofem 4 expression presents a direct indicator for workers of the "fitness value" of a queen as the sole egg layer within a colony (Korb, 2015). This is plausible as the expression of CYP4 genes can be regulated by JH (Zhou et al., 2007). If Neofem4 expression is contingent on high $\mathrm{JH}$ titers, only highly fertile individuals could produce the royalty scent. This makes Neofem 4 a good candidate to act as fertility signal.

Currently, we cannot exclude that Neofem 2 also functions via chemical communication. It might be involved in the production of a volatile, as the similarity to Lma-p72 from the Maderian cockroach implies (Cornette et al., 2003). Hence, Neofem 2 may represent the volatile part, and Neofem 4 the contact part, of the two component system that is necessary for effective maintenance of reproductive division of labor in kalotermitids. However, due to the small body size of the termites it will be difficult to demonstrate a potential communication function of Neofem 2 .

\section{HOW WIDESPREAD ARE THE NEOFEM GENES ACROSS TERMITES? IMPLICATIONS FOR EVOLUTION AND FUNCTION}

\section{Comparison with the Congeneric Species, Cryptotermes cynocephalus}

Using the same methods as applied to identify the Neofem genes in $C$. secundus, it has been tested whether the same genes underlie reproductive division of labor in the closely related species Cryptotermes cynocephalus (Weil et al., 2009b; Tables 1, 2). Fourteen genes are significantly over-expressed in $C$. cynocephalus queens, including Neofem 1, 2, and 3. For six genes (Neofem6-11) orthologous sequences are present in C. secundus while they are lacking for Neofem 12-16. QT RT PCR showed that Neofem6 is also slightly over-expressed in C. secundus queens. Neofem 6 is related to antennal expressed genes of mosquitoes that are homologs of the Drosophila melanogaster protein takeout. Proteins of this family have also been described for social insects, including termites (Hojo et al., 2005; Hagai et al., 2007). Takeout-like proteins can be involved in the regulation of feeding, courtship, and mating behavior by regulating the antennal response to odors (Dauwalder et al., 2002; Bohbot and Vogt, 2005). In the rhinotermitid Reticulitermes flavipes, deviate, a gene from the takeout family, may be involved in trail-following behavior (Schwinghammer et al., 2011). The up-regulation of Neofem7-11 in female neotenics is exclusively in C. cynocephalus and not in C. secundus. Altogether this suggests that Neofem1, 2, 3 , and 6 may be conserved "queen genes," while the remaining are more likely to be species-specific. This implies that queen signal regulation evolves quickly.

\section{Comparisons across Termites and Cockroaches}

The availability of two termite genomes from two further termite families, the dampwood termite Zootermopsis nevadensis (Archotermopsidae) (Terrapon et al., 2014) and the fungus- growing termite Macrotermes natalensis (Termitidae, Macrotermitinae) (Poulsen et al., 2014) (Table 2), together with caste-specific transcriptome data for the former, allows us to study the presence of Neofem genes across termite families with different social complexities (Korb et al., 2015). Similar to $C$. secundus, $Z$. nevadensis is a wood-dwelling termite with

TABLE 2 | Traits for main termite study species mentioned in the text.

\begin{tabular}{|c|c|c|c|c|}
\hline Species & Family & Life type & Mode of food acquisition & Social complexity \\
\hline Zootermopsis nevadensis & Archotermopsidae & One piece nester & Wood-dweller & simple \\
\hline Hodotermopsis sjostedti & Archotermopsidae & One piece nester & Wood-dweller & simple \\
\hline Cryptotermes secundus & Kalotermitidae & One piece nester & Wood-dweller & simple \\
\hline Cryptotermes cynocephalus & Kalotermitidae & One piece nester & Wood-dweller & simple \\
\hline Reticulitermes flavipes & Rhinotermitidae & Separate pieces nester & Foraging & intermediate \\
\hline Reticulitermes speratus & Rhinotermitidae & Separate pieces nester & Foraging & intermediate \\
\hline Macrotermes natalensis & Termitidae & Separate pieces nester & Foraging & complex \\
\hline
\end{tabular}


totipotent workers (Table 2). However, pathogen load differs considerably between species. C. secundus is a drywood termite that has few pathogens, while $Z$. nevadensis nests in decaying wood with a high pathogen load (Rosengaus et al., 2003). M. natalensis belongs to the higher termites (Termitidae), has large, complex colonies, and two morphologically specialized, sterile worker castes of defined instars with arrested development. Caste fate is probably determined already at the egg stage, maybe through maternally transmitted $\mathrm{JH}$, as has been suggested for another Macrotermes species (Lanzrein et al., 1985; Okot-Kotber, 1985). Here, measurements of JH titers in eggs and queens from mature colonies revealed a significant positive correlation and high fluctuations between seasons that lead to the suggestion of a direct maternal influence on caste determination (Lanzrein et al., 1985). Hence, the mechanism for maintaining reproductive division of labor may differ in $M$. natalensis, compared to the other two species, as it is unnecessary to inhibit workers from reproduction.

Combining these genomic data with information on other genetic data available for termites and cockroaches, I will draw conclusions and derive hypotheses about the function and evolution of Neofem genes across termites in the remaining text (Table 2).

Orthologs of Neofem 1, 2, 3, and 4 exist in both Z. nevadensis and M. natalensis (Poulsen et al., 2014; Terrapon et al., 2014; Table 1). Neofem 1 and Neofem 2 have one ortholog in each species. Neofem 1 is not caste specifically over-expressed in $Z$. nevadensis queens but the beta-glucosidase gene Neofem 2 is (Terrapon et al., 2014).

A recent phylogeny of termite and cockroach beta-glucosidase genes identified two major clusters, called beta glucosidase I (BGI) and beta glucosidase II (BGII) genes, but Neofem 2 does not belong to these clusters (Shimada and Maekawa, 2014; Figure 2A). In the rhinotermitid Reticulitermes speratus the BGI gene is mostly expressed in castes that are involved in proctodeal trophallaxis (anal feeding) and hence it may be linked to cellulose digestion (Shimada and Maekawa, 2014). In contrast, the $R$. speratus BGII gene seems to be constitutively expressed (Shimada and Maekawa, 2014). It may be involved in chemical communication in eggs (Matsuura et al., 2009). The C. secundus
A

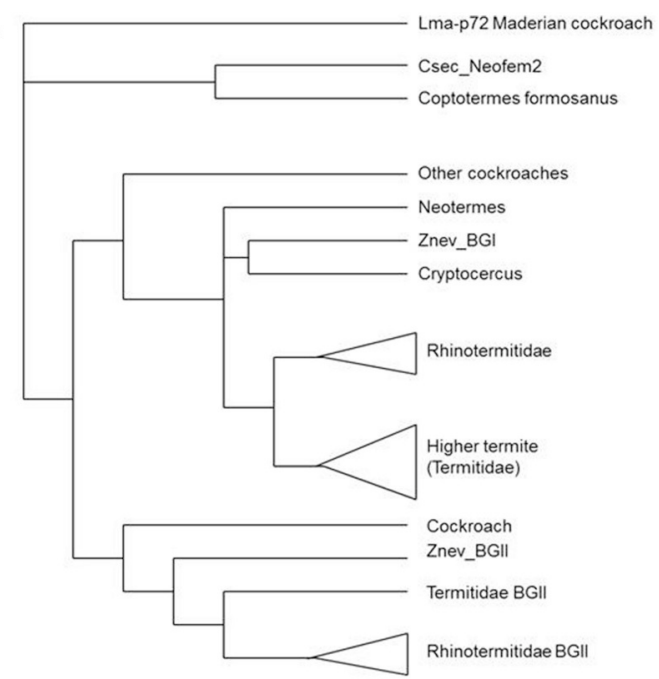

C

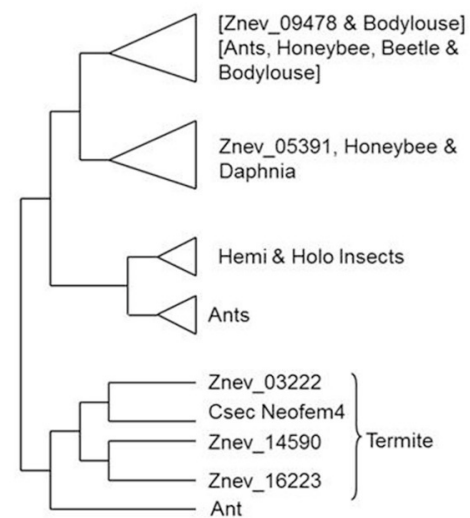

B

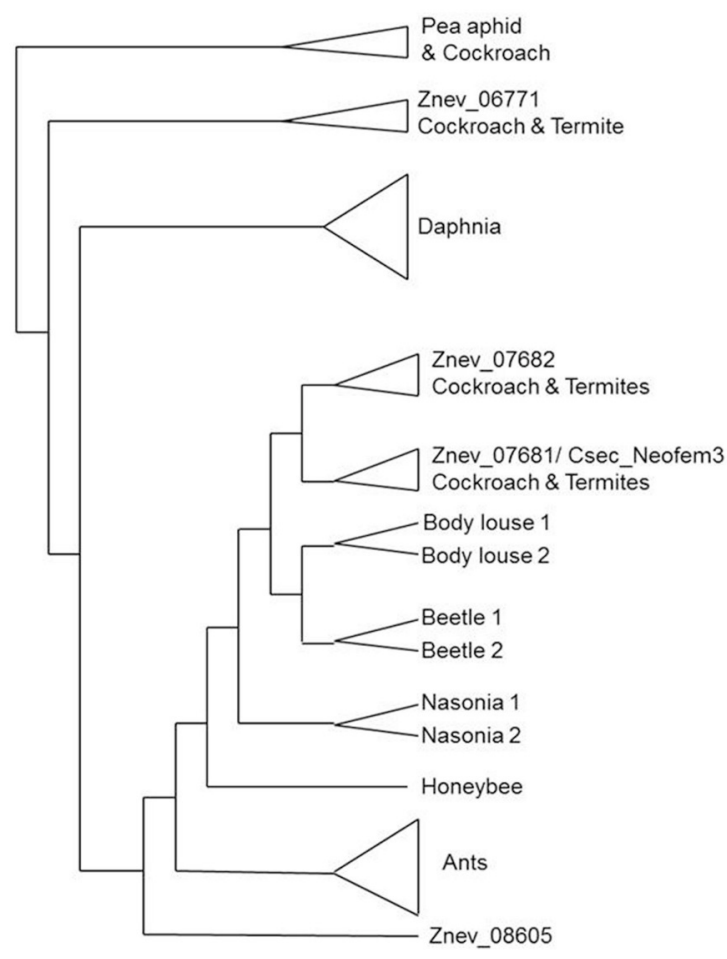

FIGURE 2 | Simplified gene trees of Neofem genes. Cladograms of (A) Neofem2-related beta-glucosidases (after Shimada and Maekawa, 2014), (B) Neofem3-related vitellogenins (after Terrapon et al., 2014), and (C) Neofem4-related Cytochrome P450 genes (after Terrapon et al., 2014 ). Beetle, Tribolium castaneum; body louse, Pediculus humanus; Cryptocercus, Cryptocercus punctulatus; Csec, Cryptotermes secundus; Daphnia, Daphnia pulex; honeybee, Apis mellifera; Maderian cockroach, Rhyparobia maderae; Nasonia, Nasonia vitripennis; pea aphid, Acyrthosiphon pisum; Znev, Zootermopsis nevadensis. 
Neofem 2 gene is outside both clusters, next to a gene from the rhinotermitid Coptotermes formosanus (JN565078), which is not further described. They build a polytomy with Lma-p72 from the Maderian cockroach (Shimada and Maekawa, 2014). The Neofem 2 ortholog from $Z$. nevadensis is missing in this tree. The tree was based on available sequence data and included additional efforts to targeted sequencing of BGI and BGII genes. Hence other beta-glucosidase genes are under-represented. Thus there are (at least) three BG lineages in termites, all probably present in cockroaches as well. One lineage (BGI) retains its common function as a digestive cellulase shared across the metazoan phylogeny, while the other two seem to be involved in chemical communication. I hypothesize that Neofem 2 is widespread in termites and that it functions as a common "queen gene." Similar to the Maderian cockroach it may produce a volatile.

Neofem 3 encodes a Vg. According to the genomic results for Z. nevadensis, there are four termite Vgs (Terrapon et al., 2014; Figure 2B): two which are adjacent to each other and have a complete domain architecture [3 Pfam domains: a Vitellogenin_N at the N-terminal region (PF01347), a von Willebrand growth factor type D domain (PF00094), and a Cterminal domain of unknown function DUF1943; PF09172], and two which both have a divergent C-terminal DUF1943 domain. The Vg gene tree implies (Figure 2B) that the two adjacent Vgs are cockroach/termite specific, they probably emerged from a recent duplication in the Blattodea ancestor. This group includes Neofem3 from C. secundus as an ortholog to vit1 from the cockroach Periplaneta americana (Storella and Kunkel, 1981). Next to this group is the conserved group of insect Vgs (including those found in social Hymenoptera) with one Z. nevadensis Vg (Znev08605) (with a divergent DUF1943) at the most basal position and Daphnia paralogs as outgroups (Figure 2B). The other divergent $\mathrm{Vg}$ is part of a separate cluster that includes some hemimetabolous insects (Figure 2B). The two "proper" Vg genes that contain all three domains are both over-expressed in neotenic females in $Z$. nevadensis (Terrapon et al., 2014). In $C$. secundus, only the expression of Neofem 3 is queen-biased while the other seems to be over-expressed in workers.

Vgs in termites have mainly been recognized for their role in reproduction and as that in reproductive division of labor. According to results for the rhinotermitid Reticulitermes aculabialis, oogenesis in workers is arrested after the oocycte growth stage so that vitellogenic oocytes are absent ( $\mathrm{Su}$ et al., 2014). Vitellogenic oocytes only occur after a reproductive molt, associated with increased $\mathrm{Vg}$ expression in female reproductives in many species (Saiki et al., 2015; reviewed in Korb, 2015). Strikingly, a doubling of DNA content through endoploidy in the fat body (i.e., the main tissue for vitellogenesis) was found in queens, but not other castes, in $R$. speratus (Nozaki and Matsuura, 2016). This may be an adaption to enable the high fecundity of termite queens, although similar duplications also exist in females of some solitary insects (e.g., Dittmann et al., 1989). In termites, as in many insects (cockroaches: Comas et al., 1999, 2001; Süeren-Castillo et al., 2012; others: Nijhout, 1994), generally high vitellogenin titers correlate with high $\mathrm{JH}$ titers (Korb et al., 2009a; Maekawa et al., 2010; reviewed in: Korb, 2015) (exception: the archotermopsid Hodotermopsis sjostedti; Cornette et al., 2008). The causal link between both was recently confirmed with RNAi experiments (Saiki et al., 2015). Down-regulation of met (Methopren-tolerant), the major receptor of $\mathrm{JH}$, resulted in inhibition of $\mathrm{Vg}$ expression in $R$. speratus neotenics.

Whether termite Vgs play a broader social role as observed in social Hymenoptera (see below) is currently unclear. However, the existence of different $\mathrm{Vg}$ genes together with their castebiased expression not only in queens (e.g., C. secundus: upregulation of Neofem 3 in kings as well as queens, up-regulation of its paralog in workers) makes this a promising avenue to explore.

P450 genes, to which Neofem 4 belongs, seem to be abundant in termites. In $Z$. nevadensis, $76 \mathrm{P} 450$ genes were identified, 55 with at least one complete P450 domain (Terrapon et al., 2014). Twenty genes belong to the CYP4 family but three had only domain fragments. Notably, global $Z$. nevadensis genome analyses identified P450s as a striking family with an overrepresentation of caste-biased expression (Terrapon et al., 2014). In total, $46 \mathrm{P} 450$ genes are differentially expressed between castes with over- or under-expression either in eggs, workers, kings, or queens. A phylogeny revealed that there are three $Z$. nevadensis genes that are closely related to Neofem 4 with Znev03222 being the supposed ortholog (Terrapon et al., 2014; Figure 2C). This gene is significantly over-expressed in $Z$. nevadensis queens and eggs, while the other two, apparently species-specific genes, are more expressed in workers and kings.

In other termites, besides a CYP6 gene in Hodotermopsis sjostedti (Cornette et al., 2006), CYP4 genes have also been identified in Mastotermes darwiniensis (Falckh et al., 1997) and $R$. flavipes (Zhou et al., 2007). Strikingly, in R. flavipes several CYP4 genes are differentially expressed during $\mathrm{JH}$-induced soldier caste differentiation (Zhou et al., 2007). The C. secundus Neofem4 gene is similar to the CYP4 genes identified in $R$. flavipes, but not at a level where they could be considered orthologous (Miura and Scharf, 2011). In addition, as in locusts and cockroaches (Helvig et al., 2004), the last step in the biosynthesis of JHIII from methylfarnesoate seems to be catalyzed by a P450 from the CYP15 family (Tarver et al., 2012). These results imply that P450 genes fulfill important functions during caste differentiation (e.g., soldier development in $R$. flavipes) as well as social organization (e.g., maintenance of reproductive division of labor in C. secundus). Whether Neofem4 is a general queen gene across termites requires further testing. It does not seem to have a queen-biased expression in C. cynocephalus (Weil et al., 2009b) but in $Z$. nevadensis it does. I hypothesize that $\mathrm{P} 450$ genes are fast evolving in termites with many lineage specific expansions, resulting in termite-specific blooms of genes especially from the CYP4 family. These blooms led to repeated, independent cooption of different copies in different lineages for social functions during termite social evolution.

\section{COMPARISON WITH SOCIAL HYMENOPTERA}

Termites evolved eusociality independent from social Hymenoptera. Hence a comparison between both can reveal insights into common and idiosyncratic mechanisms underlying 
social evolution. Nothing is known about beta-glucosidases playing an important role in the sociality of social Hymenoptera. However, there are striking commonalities for Vgs and partly for P450s.

\section{The Common Role of Vitellogenins in Social Hymenoptera and Termites}

Vitellogenins are yolk protein precursors that are crucially linked to fecundity. Hence a caste biased expression is expected to underlie reproductive division of labor. In addition, in social Hymenoptera Vgs have much broader social functions. In the honeybee, Vgs are, for instance, involved in division of labor among workers (forager vs. nurse bees, pollen vs. nectar foragers), in aging or in immune priming (e.g., Seehuus et al., 2006; Nelson et al., 2007; Page and Amdam, 2007; Rascon et al., 2011; Salmela et al., 2015). In ants, they can be differentially expressed between castes (e.g., Gräff et al., 2007; Feldmeyer et al., 2014) and also regulate maternal effects on polyphenism (Libbrecht et al., 2013).

Similar to termites, duplications of Vg genes have occurred in ants and different taxa can have different copy numbers (Wurm et al., 2010; Corona et al., 2013; Morandin et al., 2014). Strikingly, sub-functionalization occurred with caste-specific expression of different copies (Corona et al., 2013). The directionality of expression can differ between species. In addition, three Vg-like gene clades were discovered that share some sequence similarity to conventional Vgs, and are more conserved between species than the conventional Vgs (Morandin et al., 2014). Caste-biased expression of the Vg-like genes is variable among species but one Hymenoptera-specific Vg-like gene, Vg-like C, is consistently worker-biased (Morandin et al., 2014).

In the honeybee, a single conventional Vg exists. However, it is unusual as high $\mathrm{Vg}$ expression is linked to low $\mathrm{JH}$ titers in queens. Hence $\mathrm{JH}$ seems to have lost its gonadotropin function in honeybee queens, but it regulates, for instance, maturation and division of labor in the worker caste. The bumblebee, Bombus terrestris, also has a single $\mathrm{Vg}$ gene. It lives in annual colonies of lower social complexity and $\mathrm{JH}$ maintains its traditional role as a gondatropin, but $\mathrm{JH}$ titers and $\mathrm{Vg}$ expression seem to be uncoupled (Amsalem et al., 2014). Vg expression is not associated with task, and only partially with age and caste (Amsalem et al., 2014).

The current results suggest that independently in social Hymenoptera and termites, vitellogenins have been co-opted during social evolution. In the honeybee, Bombus, Vespula, and some phylogenetically basal ants only a single $\mathrm{Vg}$ exists. In other ants and termites, gene duplications seem to play an important role, and these duplications may be associated with caste-specific expression patterns. As the directionality is not conserved across taxa, this implies that after duplication different copies were "recruited" either for queen or worker function. Using separate copies for workers and queens released genes from constraints faced by potentially opposing selection pressures in both castes. Due to their high demand in reproducing insects, vitellogenins may have been particularly suitable for co-option after duplications as selection for high fertility prevented the accumulation of random mutations (having twice as much vitellogenin facilitated a higher fertility). This high demand may explain the convergence between both taxa. I hypothesize that gene duplications have been commonly co-opted during social evolution in all social insects. After a first neo- or subfunctionalization, differential selection on alternate copies may have facilitated caste specific adaptations.

\section{P450 in Social Hymenoptera}

There has been much less research emphasis on P450 genes in social Hymenoptera than in termites. The number of P450 genes vary between social Hymenoptera. In ants between 28 and 84 P450 genes have been found (Oxley et al., 2014). The honeybee has few P450 genes (only 46), especially of the CYP4 family (only 4) while CYP6 and CYP9 had some recent radiations (Claudianos et al., 2006). The Argentine ant CYP3 genes seem expanded (Smith C. D. et al., 2011). P450 genes in social Hymenoptera have mainly been discussed as enzymes detoxifying xenobiotics (Claudianos et al., 2006; Smith C. D. et al., 2011; Smith C. R. et al., 2011; Konorov and Nikitin, 2015). However, similar as in termites, they may also be important during caste differentiation. In the honeybee, several $\mathrm{P} 450$ genes show striking expression differences during development of worker- and queen- destined larvae (Cameron et al., 2013). Especially members of the CYP6 and CYP9 family have higher expression in worker larvae. As a major expression change occurs when worker-destined larvae switch to a more pollenrich food, their expression has been attributed to detoxification processes. But some P450 genes are over-expressed in queendestined larvae. As they have been linked to JH biosynthesis and ecdysteriod pathways in other species they may be promising candidates for further studies. Also in Polistes wasps P450 genes have been implicated in caste-biased gene expression (Berens et al., 2015). Hence, I hypothesize that, as in termites, P450 genes may play an important role in the sociogenomics of social Hymenoptera. This remains a promising field to uncover further common underpinnings of social evolution between the two major social insect clades, termites, and social Hymenoptera.

\section{AUTHOR CONTRIBUTIONS}

The author confirms being the sole contributor of this work and approved it for publication.

\section{ACKNOWLEDGMENTS}

I thank Graham Thompson and Miriam Richards for inviting me to contribute to this issue. Two reviewers and Graham Thompson gave helpful comments on the manuscript and improved the English. Special thanks go to Michael Rehli without whom the genetic work in C. secundus would never have been started. This work was supported by a grant (KO1895/16-1) from the Deutsche Forschungsgemeinschaft (DFG). 


\section{REFERENCES}

Amdam, G. V., Csondes, A., Fondrk, M. K., and Page, R. E. (2006). Complex social behaviour derived from maternal reproductive traits. Nature 439, 76-78. doi: 10.1038/nature 04340

Amdam, G. V., Norberg, K., Fondrk, M. K., and Page, R. E. (2004). Reproductive ground plan may mediate colony-level selection effects on individual foraging in honey bees. Proc. Natl. Acad. Sci. U.S.A. 101, 11350-11355. doi: 10.1073/pnas.0403073101

Amsalem, E., Malka, O., Grozinger, C. M., and Hefetz, A. (2014). Exploring the role of juvenile hormone and vitellogenin in reproduction and social behavior in bumble bees. BMC Evol. Biol. 14:e45. doi: 10.1186/14712148-14-45

Berens, A. J., Hunt, J. H., and Toth, A. L. (2015). Comparative transcriptomics of convergent evolution: different genes but conserved pathways underlie caste phenotypes across lineages of eusocial insects. Mol. Biol. Evol. 32, 690-703. doi: $10.1093 / \mathrm{molbev} / \mathrm{msu} 330$

Bohbot, J., and Vogt, R. G. (2005). Antennal expressed genes of the yellow fever mosquito (Aedes aegypti L.); characterization of odorant-binding protein 10 and takeout. Insect Biochem. Mol. Biol. 35, 961-979. doi: 10.1016/j.ibmb.2005.03.010

Cameron, R. C., Duncan, E. J., and Dearden, P. K. (2013). Biased gene expression in early honeybee larval development. BMC Genomics 14:e903. doi: 10.1186/14712164-14-903

Claudianos, C., Ranson, H., Johnson, R. M., Biswas, S., Schuler, M. A., Berenbaum, M. R., et al. (2006). A deficit of toxification enzymes: pesticide sensitivity and enviornmental response in the honeybee. Insect Mol. Biol. 15, 615-636. doi: 10.1111/j.1365-2583.2006.00672.x

Comas, D., Piulachs, M. D., and Belles, X. (1999). Fast induction of vitellogenin gen expression by juvenile hormone III in the cockroach Blattella germanica (L.) (Dictyoptera, Blattellidae). Insect Biochem. Mol. Biol. 29, 821-827. doi: 10.1016/S0965-1748(99)00058-2

Comas, D., Piulachs, M. D., and Bellés, X. (2001). Induction of vitellogenin gene transcription in vitro by juvenile hormone in Blattella germanica. Mol. Cell Endocrinol. 183, 93-100. doi: 10.1016/S0303-7207(01)00589-5

Cornette, R., Farine, J. P., Abed-Viellard, D., Quennedey, B., and Brossut, R. (2003). Molecular characterization of a male-specific glycosyl hydrolase, Lma-p72, secreted on to the abdominal surface of the Madeira cockroach Leucophaea maderae (Blaberidae, Oxyhaloinae). Biochem. J. 372, 535-541. doi: 10.1042/bj20030025

Cornette, R., Gotoh, H., Koshikawa, S., and Miura, T. (2008). Juvenile hormone titers and caste differentiation in the damp-wood termite Hodotermopsis sjostedti (Isoptera, Termopsidae). J. Insect Physiol. 54, 922-930. doi: 10.1016/j.jinsphys.2008.04.017

Cornette, R., Koshikawa, S., Hojo, M., Matsumoto, T., and Miura, T. (2006). Castespecific cytochrome P450 in the damp-wood termite Hodotermopsis sjostedti (Isoptera, Termopsidae). Insect Mol. Biol. 15, 235-244. doi: 10.1111/j.13652583.2006.00632.x

Corona, M., Libbrecht, R., Wurm, Y., Riba-Grognuz, O., Studer, R. A., and Keller, L. (2013). Vitellogenin underwent subfunctionalization to acquire caste and behavioral specific expression in the harvester ant Pogonomyrmex barbatus. PLoS Genet. 9:e1003730. doi: 10.1371/journal.pgen.1003730

Darwin, C. (1859). On the Origin of Species by Means of Natural Selection. London: John Murray.

Dauwalder, B., Tsujimoto, S., Moss, J., and Mattox, W. (2002). The Drosophila takeout gene is regulated by the somatic sex-determination pathway and affects male courtship behavior. Genes Dev. 16, 2879-2892. doi: 10.1101/gad.1010302

Dittmann, F., Kogen, P. H., and Hagedorn, H. H. (1989). Ploidy levels and DNA synthesis in fat body cells of the adult mosquito, Aedes aegypti: the role of juvenile hormone. Arch. Insect Biochem. Physiol. 12, 133-143. doi: 10.1002/arch.940120302

Engel, M. S., Grimaldi, D. A., and Krishna, K. (2009). Termites (Isoptera): their phylogeny, classification, and rise to ecological dominance. Am. Mus. Novit. 3650, 1-27. doi: 10.1206/651.1

Falckh, P. H., Balcombe, W., Haritos, V. S., and Ahokas, J. T. (1997). Isolation and identification of a cytochrome P450 sequence in an Australian termite, Mastotermes darwiniensis. Biochem. Biophys. Res. Commun. 241, 579-583. doi: 10.1006/bbrc. 1997.7856
Feldmeyer, B., Elsner, D., and Foitzik, S. (2014). Gene expression patterns associated with caste and reproductive status in ants: worker-specific genes are more derived than queen-specific ones. Mol. Ecol. 23, 151-161. doi: $10.1111 /$ mec. 12490

Feyereisen, R. (2012). "Insect CYP genes and P450 enzymes," in Insect Molecular Biology and Biochemistry, ed L. I. Gilbert (London: Academic Press), 236-316.

Gräff, J., Jemielity, S., Parker, J. D., Parker, K. M., and Keller, L. (2007). Differential gene expression between adult queens and workers in the ant Lasius niger. Mol. Ecol. 16, 675-683. doi: 10.1111/j.1365-294X.2007.03162.x

Hagai, T., Cohen, M., and Bloch, G. (2007). Genes encoding putative Takeout/juvenile hormone binding proteins in the honeybee (Apis mellifera) and modulation by age and juvenile hormone of the take-out gene GB19811. Insect Biochem. Mol. Biol. 37, 689-701. doi: 10.1016/j.ibmb.2007.04.002

Hamilton, W. D. (1963). The evolution of altruistic behavior. Am. Nat. 97, 354-356. doi: $10.1086 / 497114$

Hamilton, W. D. (1964). The genetical evolution of social behaviour I \& II. J. Theor. Biol. 7, 1-52. doi: 10.1016/0022-5193(64)90038-4

Heinze, J., and Hölldobler, B. (1995). Thelytokous parthenogenesis and dominance hierarchies in the ponerine ant, Platythyrea punctata (F. Smith). Naturwissenschaften 82, 40-41.

Helvig, C., Koener, J. F., Unnithan, G. C., and Feyereisen, R. (2004). CYP15A1, the cytochrome P450 that catalyzes epoxidation of methyl farnesoate to juvenile hormone III in cockroach corpora allata. Proc. Natl. Acad. Sci. U.S.A. 101, 4024-4029. doi: 10.1073/pnas.0306980101

Himuro, C., Yokoi, T., and Matsuura, K. (2011). Queen-specific volatile in a higher termite Nasutitermes takasagoensis (Isoptera: Termitidae). J. Insect Physiol. 57, 962-965. doi: 10.1016/j.jinsphys.2011.04.012

Hoffmann, K., Foster, K. R., and Korb, J. (2012). Nest value mediates reproductive decision making within termite societies. Behav. Ecol. 23, 1203-1208. doi: 10.1093/beheco/ars103

Hoffmann, K., Gowin, J., Hartfelder, K., and Korb, J. (2014). The scent of royalty: a P450 gene signals reproductive status in a social insect. Mol. Biol. Evol. 31, 2689-2696. doi: 10.1093/molbev/msu214

Hoffmann, K., and Korb, J. (2011). Is there conflict over direct reproduction in lower termite colonies? Anim. Behav. 81, 265-274. doi: 10.1016/j.anbehav.2010.10.017

Hojo, M., Morioka, M., Matsumoto, T., and Miura, T. (2005). Identification of soldier caste-specific protein in the frontal gland of nasute termite Nasutitermes takasagoensis (Isoptera: Termitidae). Insect Biochem. Mol. Biol. 35, 347-354. doi: 10.1016/j.ibmb.2005.01.007

Howard, R. W., and Blomquist, G. J. (2005). Ecological, behavioral, andbiochemical aspects of insect hydrocarbons. Annu. Rev. Entomol. 50, 371-393. doi: 10.1146/annurev.ento.50.071803.130359

Inward, D., Beccaloni, G., and Eggleton, P. (2007). Death of an order: a comprehensive molecular phylogenetic study confirms that termites are eusocial cockroaches. Biol. Lett. 3, 331-335. doi: 10.1098/rsbl.2007.0102

Konorov, E. A., and Nikitin, M. A. (2015). Amplification of CYP9 genes as a preadaptation of the black garden ant Lasius niger to urban conditions. Mol. Biol. 49, 403-407. doi: 10.1134/S0026893315030103

Korb, J. (2008). Termites, hemimetabolous diploid white ants? Front. Zool. 5:e15. doi: 10.1186/1742-9994-5-15

Korb, J. (2015). "Juvenile hormone, a central regulator of termite caste polyphenism," in Advances in Insect Physiology Vol. 48, eds A. Zayed and C. F. Kent (Oxford: Elsevier), 132-161.

Korb, J., and Hartfelder, K. (2008). Life history and development - a framework for understanding the ample developmental plasticity in lower termites. Biol. Rev. 83, 295-313. doi: 10.1111/j.1469-185X.2008.00044.x

Korb, J., Hoffmann, K., and Hartfelder, K. (2009a). Endocrine signatures underlying plasticity in postembryonic development of a lower termite, Cryptotermes secundus (Kalotermitidae). Evol. Dev. 11, 269-277. doi 10.1111/j.1525-142X.2009.00329.x

Korb, J., and Katrantzis, S. (2004). Influence of environmental conditions on the expression of the sexual dispersal phenotype in a lower termite: implications for the evolution of workers in termites. Evol. Dev. 6, 342-352. doi: 10.1111/j.1525142X.2004.04042.x

Korb, J., Poulsen, M., Hu, H., Li, C., Boomsma, J. J., Zhang, G., et al. (2015). A genomic comparison of two termites with different social complexity. Front. Genet. 6:e9. doi: 10.3389/fgene.2015.00009 
Korb, J., Weil, T., Hoffmann, K., Foster, K. R., and Rehli, M. (2009b). A gene necessary for reproductive suppression in termites. Science 324, 758-758. doi: 10.1126/science. 1170660

Lanzrein, B., Gentinetta, V., and Fehr, R. (1985). "Tutres of juvenile hormone and ecdysteriods in reproductives and eggs of Macrotermes michaelseni: relation to caste determination?" in Caste Differentiation in Social Insects, eds J. A. L. Watson, B. M. Okot-Kotber, and C. Noirot (Oxford: Pergamon Press), 307-327.

Lenz, M. (1976). "The dependence of hormone effects in termite caste determination on external factors," in Phase and Caste Determination in Insects - Endocrine Aspects, ed M. Lüscher (Oxford: Pergamon Press), 73-89.

Libbrecht, R., Corona, M., Wende, F., Azevedo, D. O., Serrão, J. E., and Keller, L. (2013). Interplay between insulin signaling, juvenile hormone, and vitellogenin regulates maternal effcets on polyphenism in ants. Proc. Natl. Acad. Sci. U.S.A. 110, 11050-11055. doi: 10.1073/pnas.1221781110

Liebig, J. (2010). "Hydrocarbon profiles indicate fertility and dominance status in ant, bee, and wasp colonies," in Insect Hydrocarbons. Biology, Biochemistry, and Chemical Ecology, eds G. J. Blomquist and A. G. Bagneres (Cambridge: Cambridge University Press), 254-281.

Liebig, J., Eliyahu, D., and Brent, C. S. (2009). Cuticular hydrocarbon profiles indicate reproductive status in the termite Zootermopsis nevadensis. Behav. Ecol. Sociobiol. 63, 179-187. doi: 10.1007/s00265-009-0807-5

Lo, N., Tokuda, G., and Watanabe, H. (2011). "Evolution and function of endogenous termite cellulases," in Biology of Termites: A Modern Synthesis, eds D. E. Bignell, Y. Roisin, and N. Lo, N. (Dordrecht: Springer), 51-68.

Lu, K. H., Bradfield, J. Y., and Keeley, L. L. (1999). Juvenile hormone inhibition of gene expression for cytochrome P4504C1 in adult females of the cockroach, Blaberus discoidalis. Insect Biochem. Mol. Biol. 29, 667-673. doi: 10.1016/S09651748(99)00034-X

Lüscher, M. (1974). "Kasten und kastendifferenzierung bei niederen termiten," in Sozialpolymorphismus bei Insekten, ed G. H. Schmidt (Stuttgart: Wissenschaftliche Verlagsgesellschaft), 694-739.

Maekawa, K., Ishitani, K., Gotoh, H., Cornette, R., and Miura, T. (2010). Juvenile hormone titre and vitellogenin gene expression related to ovarian development in primary reproductives compared with nymphs and nymphoid reproductives of the termite Reticulitermes speratus. Physiol. Entomol. 35, 52-58. doi: 10.1111/j.1365-3032.2009.00711.x

Matsuura, K. (2012). Multifunctional queen pheromone and maintenance of reproductive harmony in termite colonies. J. Chem. Ecol. 38, 746-754. doi: 10.1007/s10886-012-0137-3

Matsuura, K., Himuro, C., Yokoi, T., Yamamoto, Y., Vargo, E. L., and Keller, L. (2010). Identification of a pheromone regulating caste differentiation in termites. Proc. Natl. Acad. Sci. U.S.A. 107, 12963-12968. doi: 10.1073/pnas.1004675107

Matsuura, K., Yashiro, T., Shimizu, K., Tatsumi, S., and Tamura, T. (2009). Cuckoo fungus mimics termite eggs by producing the cellulose-digesting enzyme betaglucosidase. Curr. Biol. 19, 30-36. doi: 10.1016/j.cub.2008.11.030

Miura, T., and Scharf, M. E. (2011). "Molecular basis underlying caste differentiation in termites," in Biology of Termites: A Modern Synthesis, eds D. E. Bignell, Y. Roisin, and N. Lo (Dordrecht: Springer), 211-254.

Morandin, C., Havukainen, H., Kulmuni, J., Dhaygude, K., Trontti, K., and Helanterä, H. (2014). Not only for egg yolk - functional and evolutionary insughts from expression, selection, and structural analyses of Formica ant vitellogenins. Mol. Biol. Evol. 31, 2181-2193. doi: 10.1093/molbev/msu171

Nelson, C. M., Ihle, K. E., Fondrk, M. K., Page, R. E., and Amdam, G. V. (2007). The gene vitellogenin has multiple coordinating effects on social organization. PLoS Biol. 5:e62. doi: 10.1371/journal.pbio.0050062

Nijhout, H. F. (1994). Insect Hormones. Princeton: Princeton University Press.

Noirot, C. (1985a). "The caste system in higher termites," in Caste Differentiation in Social Insects, eds J. A. L. Watson, B. M. Okot-Kotber, and C. Noirot (Oxford: Pergamon Press), 75-86.

Noirot, C. (1985b). "Pathways of caste development in the lower termites," in Caste Differentiation in Social Insects, eds J. A. L. Watson, B. M. Okot-Kotber, and C. Noirot (Oxford: Pergamon Press), 41-58.

Nozaki, T., and Matsuura, K. (2016). Termite queens have disproportionately more DNA in their fat body cells: reproductive division of labor and endoreduplication. Entomol. Sci. 19, 67-71. doi: 10.1111/ens. 12156
Okot-Kotber, B. M. (1985). "Mechanisms of caste determination in a higher termite, Macrotermes michaelseni (Isoptera, Macrotermitidae)," in Caste Differentiation in Social Insects, eds J. A. L. Watson, B. M. Okot-Kotber, and C. Noirot (Oxford: Pergamon Press), 267-306.

Oxley, P. R., Ji, L., Fetter-Pruneda, I., McKenzie, S. K., Li, C., Hu, H., et al. (2014). The genome of the clonal raider ant Cerapachys biroi. Curr. Biol. 24, 451-458. doi: 10.1016/j.cub.2014.01.018

Page, R. E. Jr., and Amdam, G. V. (2007). The making of a social insect: developmental architectures of social design. Bioessays 29, 334-343. doi: 10.1002/bies.20549

Poulsen, M., Hu, H., Li, C., Chen, Z., Xu, L., Otani, S., et al. (2014). Complementary symbiont contributions to plant decomposition in a fungus-farming termite. Proc. Natl. Acad. Sci. U.S.A. 111, 14500-14505. doi: 10.1073/pnas.1319718111

Queller, D. C., and Strassmann, J. E. (1998). Kin selection and social insects. BioSci. 48, 165-175. doi: 10.2307/1313262

Rascon, B., Mutti, N. S., Tolfsen, C., and Amdam, G. (2011). "Honey bee life history plasticity: development, behavior, and aging," in Mechanisms of Life History Evolution, eds T. Flatt and A. Heyland (Oxford: Oxford University Press), 253-266.

Ratnieks, F. L. W., Foster, K. R., and Wenseleers, T. (2006). Conflict resolution in insect societies. Annu. Rev. Entomol. 51, 581-608. doi: 10.1146/annurev.ento.51.110104.151003

Reed, J. R., Vanderwel, D., Choi, S. W., Pomonis, J. G., Reitz, R. C., and Blomquist, G. J. (1994). Unusual mechanism of hydrocarbon formation in the housefly Cytochrome-P450 converts aldehyde to the sex-pheromone component (Z)9-tricosene and CO2. Proc. Natl. Acad. Sci. U.S.A. 91, 10000-10004. doi: 10.1073/pnas.91.21.10000

Roisin, Y. (2000). "Diversity and evolution of caste patterns," in Diversity and Evolution of Caste Patterns, eds T. Abe, D. E. Bignell, and M. Higashi (Dordrecht: Kluwer Academic Publishers), 95-119.

Roisin, Y., and Korb, J. (2011). "Social organisation and the status of workers in termites," in Biology of Termites: A Modern Synthesis, eds D. E. Bignell, Y. Roisin, and N. Lo (Dordrecht: Springer), 133-164.

Rosengaus, R. B., Moustakas, J. E., Calleri, D. V., and Traniello, J. F. A. (2003). Nesting ecology and cuticular microbial loads in dampwood (Zootermopsis angusticollis) and drywood termites (Incisitermes minor, I. Schwarzi, Cryptotermes cavifrons). J. Insect Sci. 3, 31. doi: 10.1673/031.003.3101

Saha, P., Balasubramaniam, K. N., Kalyani, J. N., Supriya, K., Padmanabhan, A., and Gadagkar, R. (2012). Clinging to royalty: Ropalidia marginata queens can employ both pheromone and aggression. Insect. Soc. 59, 41-44. doi: 10.1007/s00040-011-0185-7

Saiki, R., Gotoh, H., Toga, K., Miura, T., and Maekawa, K. (2015). High juvenile hormone titre and abdominal activation of $\mathrm{JH}$ signalling may induce reproduction of termite neotenics. Insect Mol. Biol. 24, 432-441. doi: $10.1111 /$ imb. 12169

Salmela, H., Amdam, G. V., and Freitak, D. (2015). Transfer of immunity from mother to offspring is mediated via egg-yolk protein vitellogenin. PLoS Pathog. 11:e1005015. doi: 10.1371/journal.ppat.1005015

Schwinghammer, M. A., Zhou, X., Kambhampati, S., Bennett, G. W., and Scharf, M. E. (2011). A novel gene from the takeout family involved in termite trail-following behavior. Gene 474, 12-21. doi: 10.1016/j.gene.2010.11.012

Seehuus, S. C., Norberg, K., Gimsa, U., Krekling, T., and Amdam, G. V. (2006). Reproductive protein protects functionally sterile honey bee workers from oxidative stress. Proc. Natl. Acad. Sci. U.S.A. 103, 962-967. doi: 10.1073/pnas.0502681103

Shimada, K., and Maekawa, K. (2014). Gene expression and molecular phylogenetic analyses of beta-glucosidase in the termite Reticulitermes speratus (Isoptera: Rhinotermitidae). J. Insect Physiol. 65, 63-69. doi: 10.1016/j.jinsphys.2014.05.006

Smith, C. D., Zimin, A., Holt, C., Abouheif, E., Benton, R., Cash, E., et al. (2011). Draft genome of the globally widespread and invasive Argentine ant (Linepithema humile). Proc. Natl. Acad. Sci. U.S.A. 108, 5673-5678. doi: 10.1073/pnas. 1008617108

Smith, C. R., Smith, C. D., Robertson, H. M., Helmkampf, M., Zimin, A., Yandell, M., et al. (2011). Draft genome of the red harvester ant Pogonomyrmex barbatus. Proc. Natl. Acad. Sci. U.S.A. 108, 5667-5672. doi: $10.1073 /$ pnas. 1007901108 
Storella, J. R., and Kunkel, J. G. (1981). 2 vitellogenins in Periplaneta americana. J. Cell Biol. 91, 393A.

Su, X.-H., Wei, Y.-H., and Liu, M.-H. (2014). Ovarian development and modes of apoptosis during oogenesis in various castes of the termite Reticulitermes aculabialis. Physiol. Entomol. 39, 44-52. doi: 10.1111/phen.12046

Süeren-Castillo, S., Abrisqueta, M., and Maestro, J. L. (2012). FOXO inhibits juvenile hormone biosynthesis and vitellogenin production in the German cockroach. Insect Biochem. Mol. Biol. 42, 491-498. doi: 10.1016/j.ibmb.2012.03.006

Sutherland, T. D., Unnithan, G. C., Andersen, J. F., Evans, P. H., Murataliev, M. B., Szabo, L. Z., et al. (1998). A cytochrome P450 terpenoid hydroxylase linked to the suppression of insect juvenile hormone synthesis. Proc. Natl. Acad. Sci. U.S.A. 95, 12884-12889. doi: 10.1073/pnas.95.22.12884

Sutherland, T. D., Unnithan, G. C., and Feyereisen, R. (2000). Terpenoid omegahydroxylase (CYP4C7) messenger RNA levels in the corpora allata: a marker for ovarian control of juvenile hormone synthesis in Diploptera punctata. J. Insect Physiol. 46, 1219-1227. doi: 10.1016/S0022-1910(00)00042-1

Tartar, A., Wheeler, M. M., Zhou, X., Coy, M. R., Boucias, D. G., and Scharf, M. E. (2009). Parallel metatranscriptome analyses of host and symbiont gene expression in the gut of the termite Reticulitermes flavipes. Biotech. Biofuels 2:e25. doi: 10.1186/1754-6834-2-25

Tarver, M. R., Coy, M. R., and Scharf, M. E. (2012). Cyp15F1 - a novel cytochrome P450 gene linked to juvenile hormone-dependent caste differentiation in the termite Reticulitermes flavipes. Arch. Insect Biochem. Physiol. 80, 92-108. doi: 10.1002/arch. 21030

Terra, W. R., Ferreira, C., Jordao, B. P., and Dillon, R. J. (1996). "Digestive enzymes," in Biology of the Insect Midgut, eds M. J. Lehane and P. F. Billingsley (London: Chapman \& Hall), 153-194.

Terrapon, N., Li, C., Robertson, H. M., Ji, L., Meng, X., Booth, W., et al. (2014). Molecular traces of alternative social organization in a termite genome. Nat. Commun. 5, 3636. doi: 10.1038/ncomms4636

Van Oystaeyen, A., Oliveira, R. C., Holman, L., van Zweden, J. S., Romero, C., Oi, C. A., et al. (2014). Conserved class of queen pheromones stops social insect workers from reproducing. Science 343, 287-290. doi: 10.1126/science.12 44899
Weil, T., Hoffmann, K., Kroiss, J., Strohm, E., and Korb, J. (2009a). Scent of a queen-cuticular hydrocarbons specific for female reproductives in lower termites. Naturwissenschaften 96, 315-319. doi: 10.1007/s00114-0080475-8

Weil, T., Korb, J., and Rehli, M. (2009b). Comparison of queen-specific gene expression in related lower termite species. Mol. Biol. Evol. 26, 1841-1850. doi: 10.1093/molbev/msp095

Weil, T., Rehli, M., and Korb, J. (2007). Molecular basis for the reproductive division of labour in a lower termite. BMC Genomics 8:198. doi: 10.1186/14712164-8-198

Wenseleers, T., Gardner, A., and Foster, K. R. (2010). "Social evolution theory: a review of methods and approaches," in Social Behaviour: Genes, Ecology and Evolution, eds T. Székely, J. Komdeur, and A. J. Moore (Cambridge: Cambridge University Press), 132-158.

Wheeler, D. (1996). The role of nourishment in oogenesis. Annu. Rev. Entomol. 41, 407-431. doi: 10.1146/annurev.en.41.010196.002203

Wilson, E. (1971). Insect Societies. Cambridge: Harvard University Press.

Wurm, Y., Wang, J., and Keller, L. (2010). Changes in reproductive roles are associated with changes in gene expression in fire ant queens. Mol. Ecol. 19, 1200-1211. doi: 10.1111/j.1365-294X.2010.04561.x

Zhou, X., Song, C., Grzymala, T. L., Oi, F. M., and Scharf, M. E. (2007). Juvenile hormone and colony conditions differentially influence cytochrome P450 gene expression in the termite Reticulitermes flavipes. Insect Mol. Biol. 15, 749-761. doi: 10.1111/j.1365-2583.2006.00675.x

Conflict of Interest Statement: The author declares that the research was conducted in the absence of any commercial or financial relationships that could be construed as a potential conflict of interest.

Copyright $\odot 2016$ Korb. This is an open-access article distributed under the terms of the Creative Commons Attribution License (CC BY). The use, distribution or reproduction in other forums is permitted, provided the original author $(s)$ or licensor are credited and that the original publication in this journal is cited, in accordance with accepted academic practice. No use, distribution or reproduction is permitted which does not comply with these terms. 